\title{
SISTEM INFORMASI PENERIMAAN DONASI ZAKAT, INFAQ DAN SHODAQOH (ZIS) BERSTANDAR PSAK 109 BERBASIS WEB (STUDI KASUS: GRAHA YATIM DAN DHUAFA)
}

\author{
Khoirotun Hisan', Lena Magdalena², Muhammad Hatta ${ }^{3}$ \\ Universitas Catur Insan Cendekia \\ Jl.Kesambi 202, Kota Cirebon, JawaBarat. Tlp: (0231)200418. \\ Email: khoirotunhisan816@gmail.com¹,lena.magdalena@cic.ac.id²,muhammad.hatta@cic.ac.id
}

\begin{abstract}
Abstrak
Penelitian yang dilakukan adalah menganalisis kelemahan dan kebutuhan Sistem Akuntansi Penerimaan Donasi ZIS Berstandar PSAK 109 Berbasis Web di Graha Yatim dan Dhuafa (GRAY) untuk diberikan usulan perbaikan berupa rancangan sistem akuntansi yang dapat memenuhi kebutuhan perusahaan agar memudahkan dalam melakukan transaksi yang dilakukan. Sistem akuntansi pencatatan penerimaan yang diusulkan membahas mengenai pembuatan Sistem Akuntansi Penerimaan Donasi Zakat, Infaq, dan Shodaqoh (ZIS) Berstandar PSAK 109 Berbasis Web, untuk memudahkan dalam proses pencatatan penerimaan donasi Zakat, Infaq dan Shodaqoh. Penelitian yang dilakukan dengan cara studi lapangan berupa wawancara kepada karyawan serta menganalisis proses bisnis yang terjadi dan dokumen-dokumen yang terkait. Dalam membuat Sistem Akuntansi Penerimaan Donasi ZIS ini menggunakan bahasa pemrograman PHP dan menggunakan Mysql sebagai databasenya. Dan untuk mendukung pembuatan form-form dan laporan-laporan yang diperlukan menggunkan Microsoft Visio 2010 dan Microsoft Excel 2010. Tujuan dibuatnya Sistem Akuntansi Penerimaan Donasi ZIS ini agar memudahkan bagian-bagian yang terkait dalam mengelola datadata transaksi yaitu transaksi penerimaan donasi ZIS dan penyaluran dana ZIS yaitu Bagian Admin Penerimaan dan Bagian Admin Pengeluaran. Selain itu dapat memudahkan Bagian Akunting dalam proses pembuatan laporan-laporan sesuai Standar PSAK No. 109. Adapun kekurangan dalam Sistem Akuntansi Penerimaan Donasi ZIS Berstandar PSAK 109 ini adalah sistem ini belum terdapat perhitungan zakat, tidak membahas dana amil dan dana non halal.
\end{abstract}

Kata kunci : Sistem, Akuntansi, Penerimaan, Donasi, Zakat, Infaq, Shodaqoh

\begin{abstract}
The research conducted was to analyze the weaknesses and needs of the ZIS Acceptance Accounting System PSAK Standard 109 Web-Based in Graha Yatim and Dhuaafa (GRAY) to be given a proposed improvement, in the form of an accounting system that can meet the needs of the company. The proposed accounting accounting system discusses the making of an ZIS Donation Acceptance Accounting. System, Standardized in PSAK 109, to facilitate the recording of receipt of Zakat, Infaq and Shodaqoh donations. Research carried out by means of field studies in the form of interviews with employees and analyze the business processes that occur and related documents. In making this ZIS Donation Acceptance Accounting System using the PHP programming language and using the Mysql database. And to support the creation of forms and reports using Microsoft Visio 2010 and Microsoft Excel 2010. The purpose of making this ZIS Donation Acceptance Accounting System is to facilitate the relevant parts in managing transaction data, namely the receipt of ZIS donation transactions and the distribution of ZIS funds. In addition it can facilitate the process of making related reports. As for the shortcomings in the Accounting System for Acceptance of the Standardized ZIS Donation PSAK 109, this system does not yet have zakat calculations, it does not discuss amil funds and non-halal funds.
\end{abstract}

Keywords: System, Accounting, Acceptance, Donation, Zakat, Infaq, Shodaqoh

JURNAL DIGIT Vol. 10, No.1 Mei 2020 : 23 34 


\section{PENDAHULUAN}

Graha Yatim Dhua'fa (GRAY) - YHR, merupakan organisasi nirlaba yang didirikan sebagai salah satu unit dari Departemen Sosial Yayasan Harapan Robbani, bergerak dalam bidang kesejahteraan sosial yang bertujuan untuk menjadi salah satu unit yang dapat mengelola zakat, infaq dan shodaqoh dari para donatur (Muzakki) untuk didistribusikan kepada yang berhak menerimanya (mustahiq) termasuk untuk anakanak yatim dan dhuafa (kurang mampu). Pada saat ini Graha Yatim \& Dhuafa sudah mempunyai 15 cabang yang tersebar di beberapa kota yaitu Cirebon, Kuningan, Bekasi, Jakarta, Depok dan Surabaya. Dengan banyaknya cabang yang tersebar dibeberapa kota tersebut akan membuat semakin banyaknya data yang akan di kelola. Dalam proses pencatatannya Graha Yatim \& Dhuafa masih belum terkomputerisasi sehingga dengan banyaknya transaksi yang ada dapat menyebabkan kesalahan perhitungan dan pembuatan laporan yang sesuai dengan PSAK 109.

Pada tahun 2007 Forum Zakat bersama dengan Ikatan Akuntan Indonesia (IAI) menyusun akutansi zakat. Pada tahun 2008 IAI menyelesaikan PSAK No.109 tentang Akuntansi Zakat. Pernyataan Standar Akuntansi Keuangan (PSAK) 109 mulai berlaku efektif sejak 1 Januari 2009. PSAK ini mengikat untuk Organisasi Pengelola Zakat (OPZ) yang sudah disahkan legalitasnya oleh pemerintah. Pemberlakuan PSAK ini juga diharapkan dapat mewujudkan keseragaman pelaporan, dan kesederhanaan pencatatan. Sehingga publik dapat membaca laporan akuntansi pengelola zakat serta mengawasi pengelolaannya.

Pada penelitian sebelumnya pernah dibahas mengenai topik ini dengan judul "Sistem Informasi Manajemen Zakat, Infaq, dan Sedekah Pada Badan Amil Zakat Nasional", pada penelitian tersebut belum menerapkan PSAK 109 dan menggunakan metode RAD (Tahap Perencanaan Syarat Workshop Design dan Implementasi) serta menggunakan tools UML dengan ruang lingkup sistemnya yaitu bagian penghimpunan, bagian pendayagunaan dan admin.

Berdasarkan uraian dan penjelasan diatas maka penyusun tertarik untuk membahas mengenai sistem akuntansi zakat, infaq dan shodaqoh berstandar PSAK yang akhirnya penyusun tuangkan kedalam Skripsi Sistem Informasi dengan topik "Sistem Informasi Penerimaan Donasi Zakat, Infaq dan Shodaqoh Berstandar PSAK 109 Berbasis Web".

\section{KAJIAN PUSTAKA}

\subsection{Sistem Informasi}

"Sistem informasi adalah suatu jaringan kerja dari prosedur-prosedur yang saling berhubungan, berkumpul bersama-sama untuk melakukan suatu kegiatan atau untuk melakukan suatu kegiatan atau menyelesaikan suatu sasaran tertentu" (Jogiyanto, 2005).

Dari definisi diatas dapat disimpulkan bahwa sistem informasi adalah formulir-formulir, catatancatatan, prosedur-prosedur dan alat-alat yang digunakan untuk mengelola data dengan tujuan menghasilkan laporan dalam bentuk informasi yang dibutuhkan oleh manajemen perusahaan dan pihak-pihak lain yang berkepentingan seperti pemegang saham, kreditur dan lembaga pemerintah untuk menilai hasil operasi.

\subsection{Zakat}

Zakat adalah konsep ajaran Islam yang berlandaskan Al-Qur'an dan Sunnah bahwa harta kekayaan yang dimiliki sesorang adalam amanat dari Allah dan berfungsi sosial. Dengan demikian zakat adalah kewajiban yang diperintakan oleh Allah SWT dan hukumnya adalah fardhu 'ain. Hal tersebut dapat dilihat dari dalil baik yang terdapat dalam Al-Qur'an maupun hadis diantaranya dalam QS. Al-Baqarah (2): 43

\subsection{Infaq/Shodaqoh}

Menurut Sarip Muslim didalam buku Akuntansi Keuangan Syariah tahun 2015, infak merupakan harta (materi) yang disunnahkan untuk dikeluarakan dengan jumlah dan waktu yang tidak ditentukan. Penyalurannya tidak ditentukan penerimanya. Adapun sedekah adaah harta nonateril yang disunnahkan untuk dikerjakan. Pengertian infak sebenarnya sama dengan pengertian sedekah, termasuk juga hokum dan ketentuan-ketentuannya. Akan tetapi, jika infaq berkaitan dengan materi, sedekah memiliki arti lebih luas, menyangkut hal yang bersifat non materi.

\subsection{Sistem Pendukung Keputusan}

Sistem Pendukung Keputusan adalah sebuah sistem yang mampu memberikan kemampuan pemecahan masalah maupun kemampuan pengkomunikasian untuk masalah dengan kondisi semi-terstruktur dan situasi tidak terstruktur, dimana tak seorangpun tahu secara pasti bagaimana keputusan harus dibuat.

Sistem Informasi Penerimaan Donasi Zakat, Infaq Dan Shodaqoh (Zis) Berstandar Psak 109 Berbasis Web (Studi Kasus: Graha Yatim Dan Dhuafa) - (Khoirotun Hisan, Lena Magdalena, Muhammad Hatta) 


\subsection{PSAK 109}

Pada tahun 2007 Forum Zakat bersama dengan Ikatan Akuntan Indonesia (IAI) menyusun akutansi zakat. Pada tahun 2008 IAI menyelesaikan PSAK No.109 tentang Akuntansi Zakat. Pernyataan Standar Akuntansi Keuangan (PSAK) 109 mulai berlaku efektif sejak 1 Januari 2009. PSAK ini mengikat untuk Organisasi Pengelola Zakat (OPZ) yang sudah disahkan legalitasnya oleh pemerintah. Pemberlakuan PSAK ini juga diharapkan dapat mewujudkan keseragaman pelaporan, dan kesederhanaan pencatatan. Sehingga publik dapat membaca laporan akuntansi pengelola zakat serta mengawasi pengelolaannya.

\section{METODE ANALISA DATA}

Pada tahapan penelitian penyusun mengadopsi metode dalam pengembangan perangkat lunak menggunakan Classic Life Cycle Model. Model ini merupakan model konvensional yang sering disebut sebagai Waterfall Model karena tahapan-tahapannya yang sistematis dan berurutan dalam membangun perangkat lunak. Tahapan-tahapannya adalah sebagai berikut :Melakukan pengumpulan data dengan cara melakukan observasi dan wawancara dengan pihak terkait.

1. System Engineering (Rekayasa Sistem)

Pada tahap ini pengerjaan dimulai dengan menentukan kebutuhan untuk seluruh elemen-elemen sistem dan mengalokasikannya untuk perangkat lunak.

2. Analysis (Analisa)

Pada tahap ini akan dilakukan kegiatan penelitian, memeriksa, mempelajari, dan membandingkan data yang telah dikumpulkan dari proses sebelumnya. Selain itu tahapan ini dapat digunakan untuk mengidentifikasi masalah yang ada.

3. Design (Desain)

Pada tahap ini perancangan suatu sistem digambarkan dengan menguraikan alur sistem sampai alur dokumen yang akan dikembangkan dengan menggunakan tools antara lain : Flowchart, Flowmap, Data Flow Diagram (DFD) dan Database.

\section{HASIL DAN PEMBAHASAN}

4.1. Flowchart Penerimaan Donasi ZIS

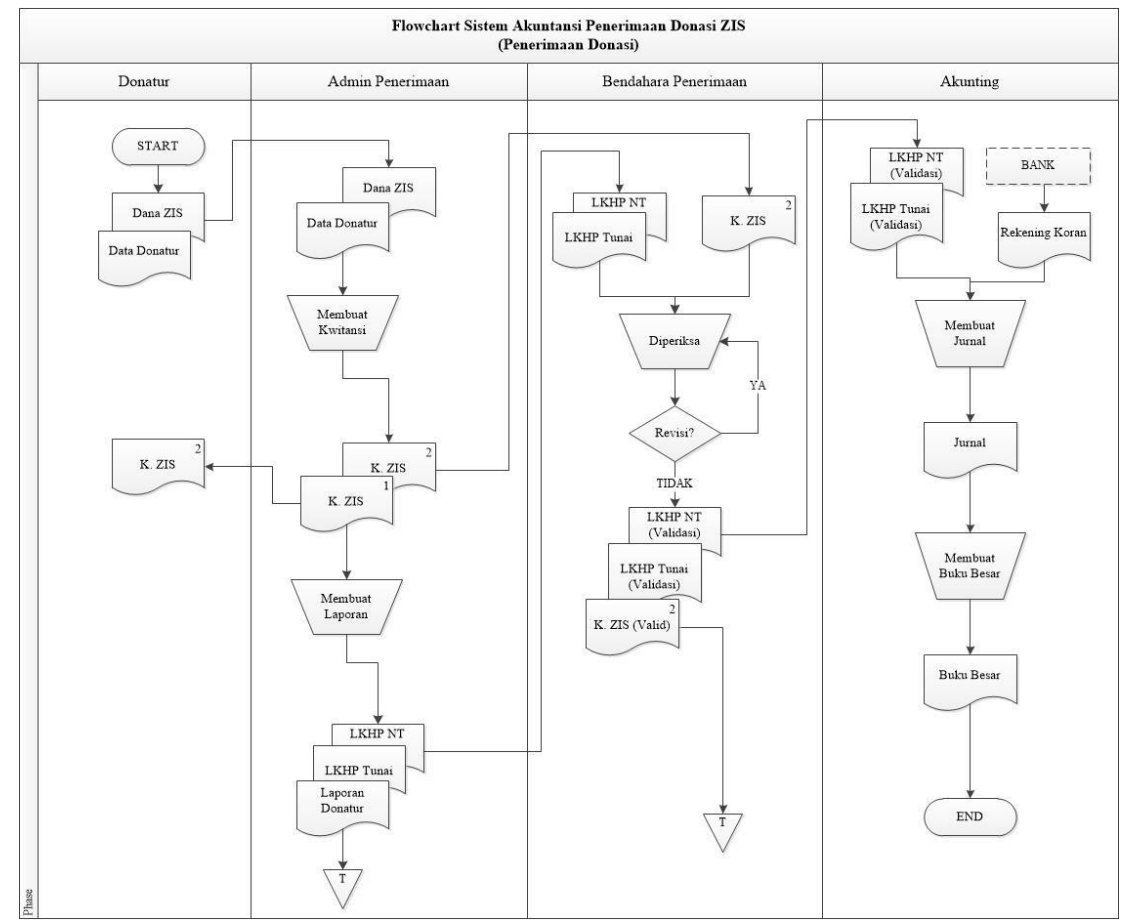

Gambar 1. Flowchart Penerimaan Donasi ZIS 
4.2. Flowchart Penyaluran Donasi ZIS

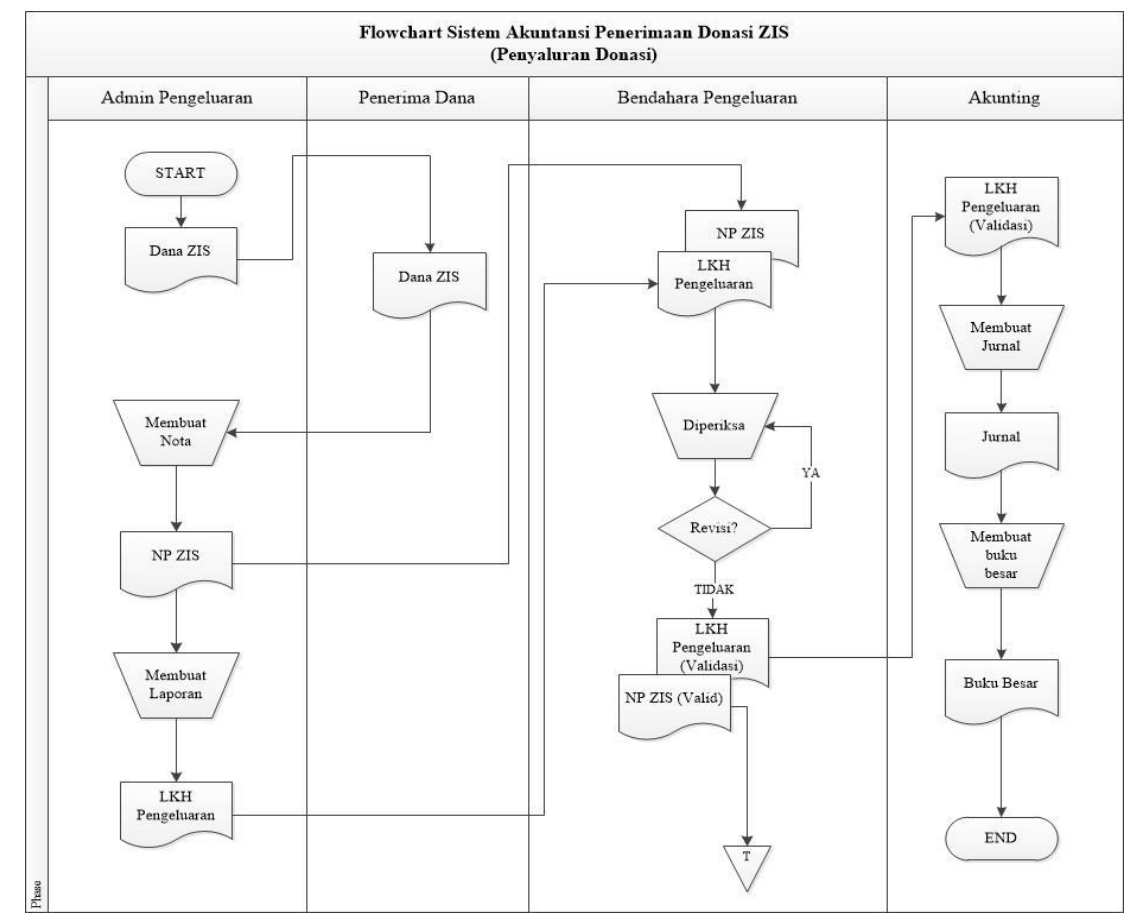

Gambar 2. Flowchart Penyaluran Donasi ZIS

\subsection{Flowchart Pembuatan Laporan PSAK 109}

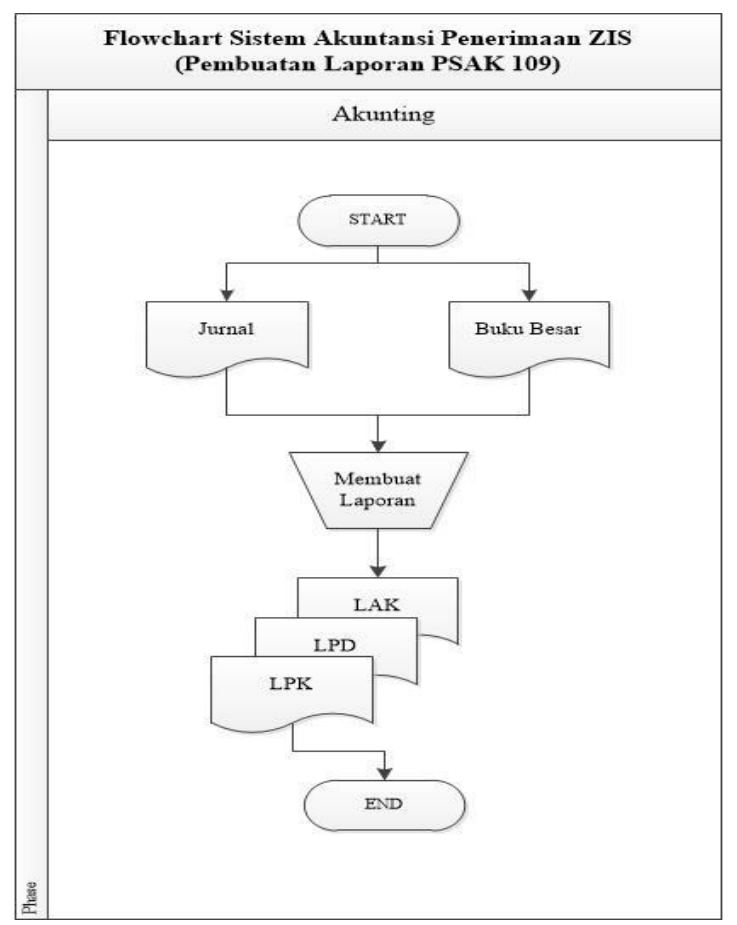

Gambar 3. Flowchart Pembuatan Laporan PSAK 109

Sistem Informasi Penerimaan Donasi Zakat, Infaq Dan Shodaqoh (Zis) Berstandar Psak 109 Berbasis Web (Studi Kasus: Graha Yatim Dan Dhuafa) - (Khoirotun Hisan, Lena Magdalena, Muhammad Hatta) 


\subsection{Flowmap Komputerisasi}

\begin{tabular}{|c|c|c|c|}
\hline \multicolumn{4}{|c|}{$\begin{array}{l}\text { FLOWMAP KOMPUTERISASI GRAY-YHR } \\
\text { SISTEM AKUNTANSI PENERIMAAN DONASI ZIS }\end{array}$} \\
\hline ADMIN PENERIMMAN & ADMIN PENGELLARAN & AKLINTING & MANAJEMEN \\
\hline
\end{tabular}

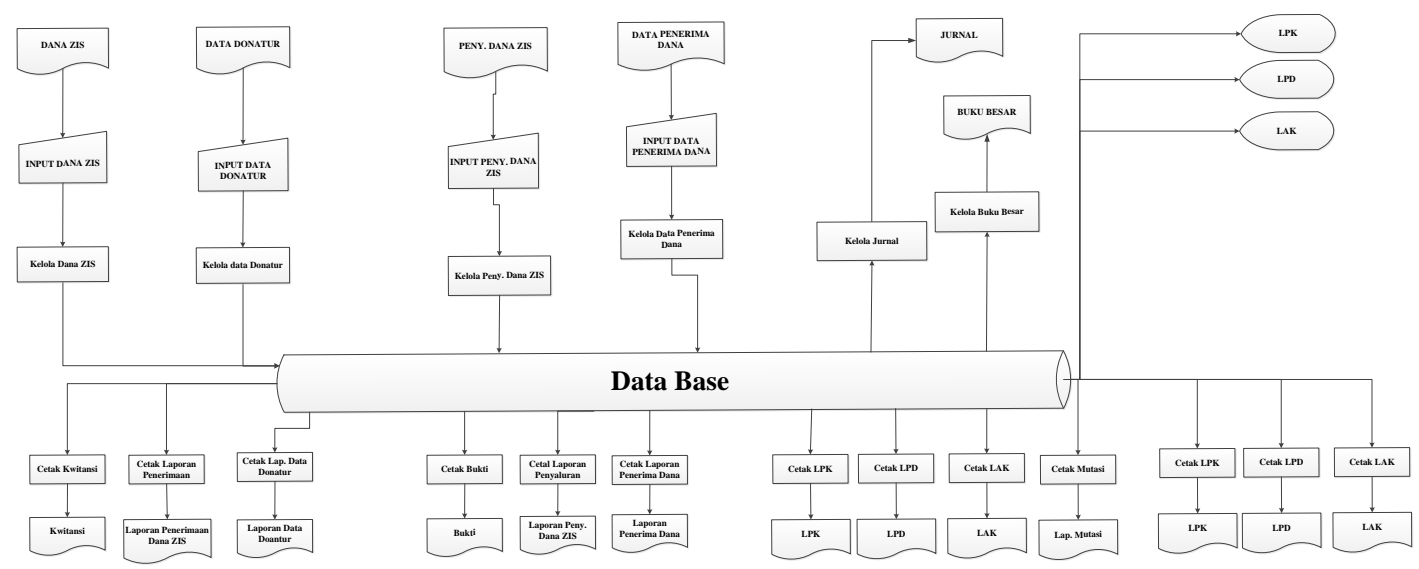

Gambar 4. Flowmap Komputerisasi

\subsection{Diagram Konteks}

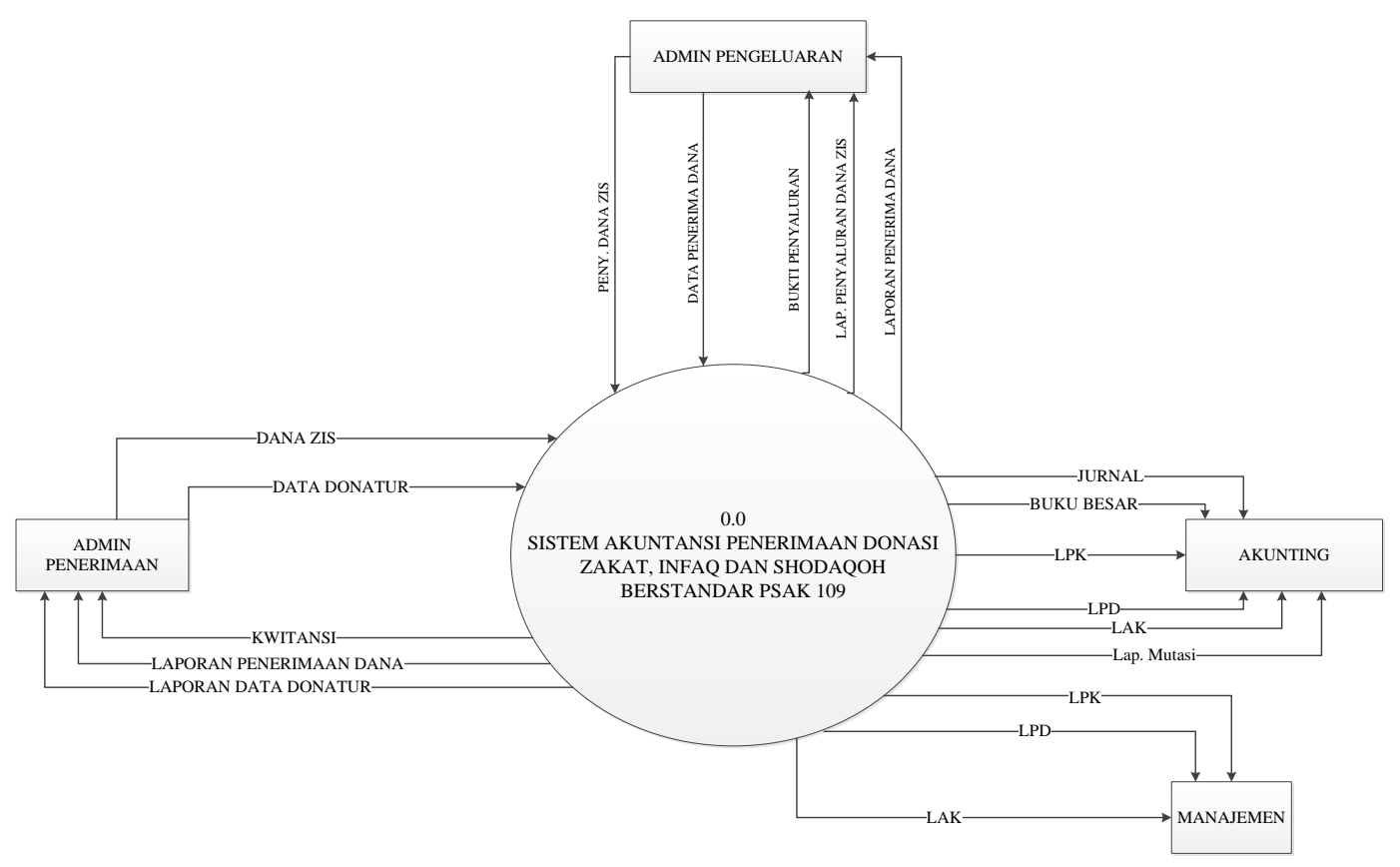

Gambar 5. Diagram Konteks 


\subsection{Diagram Level 0}



Gambar 6. Diagram Level 01

\subsection{Diagram Level 1 Proses 1}

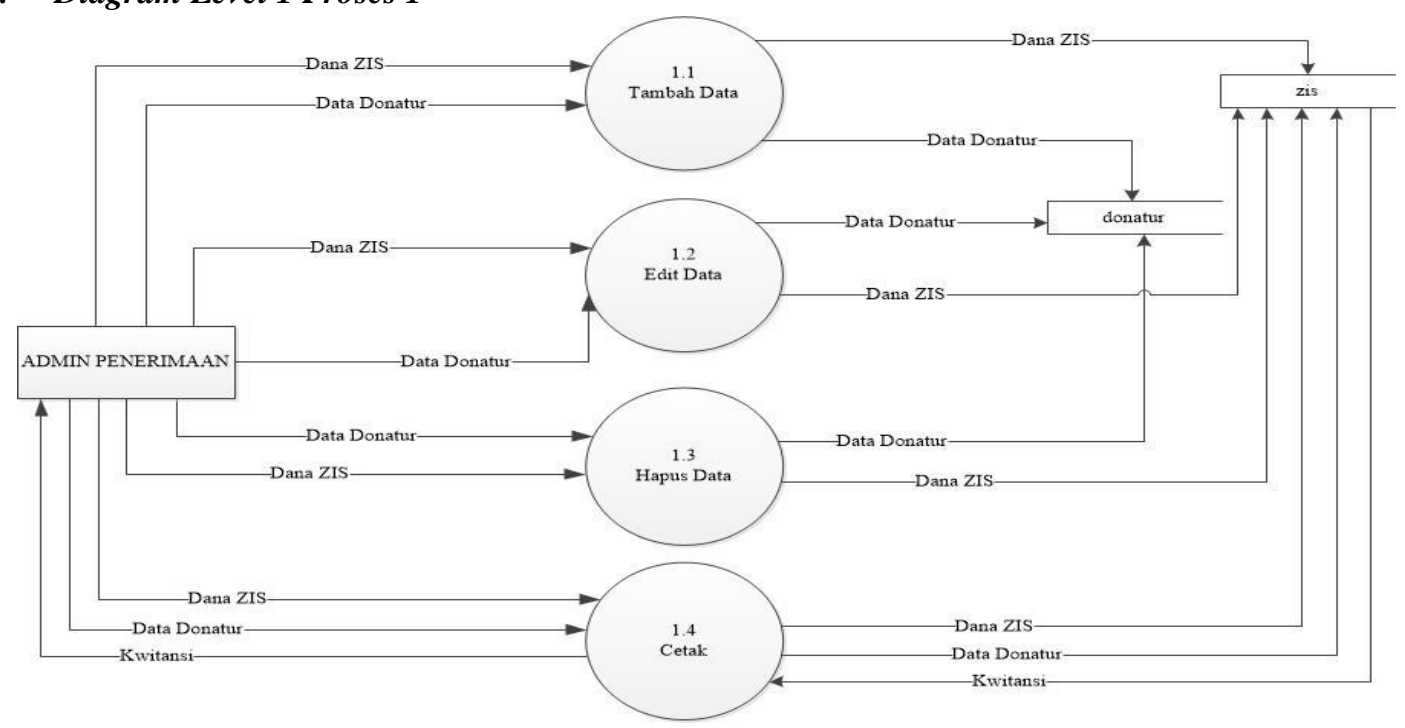

Gambar 7. Diagram Level 1 Proses 1

Sistem Informasi Penerimaan Donasi Zakat, Infaq Dan Shodaqoh (Zis) Berstandar Psak 109 Berbasis Web (Studi Kasus: Graha Yatim Dan Dhuafa) - (Khoirotun Hisan, Lena Magdalena, Muhammad Hatta ) 
4.8. Diagram Level 1 Proses 2

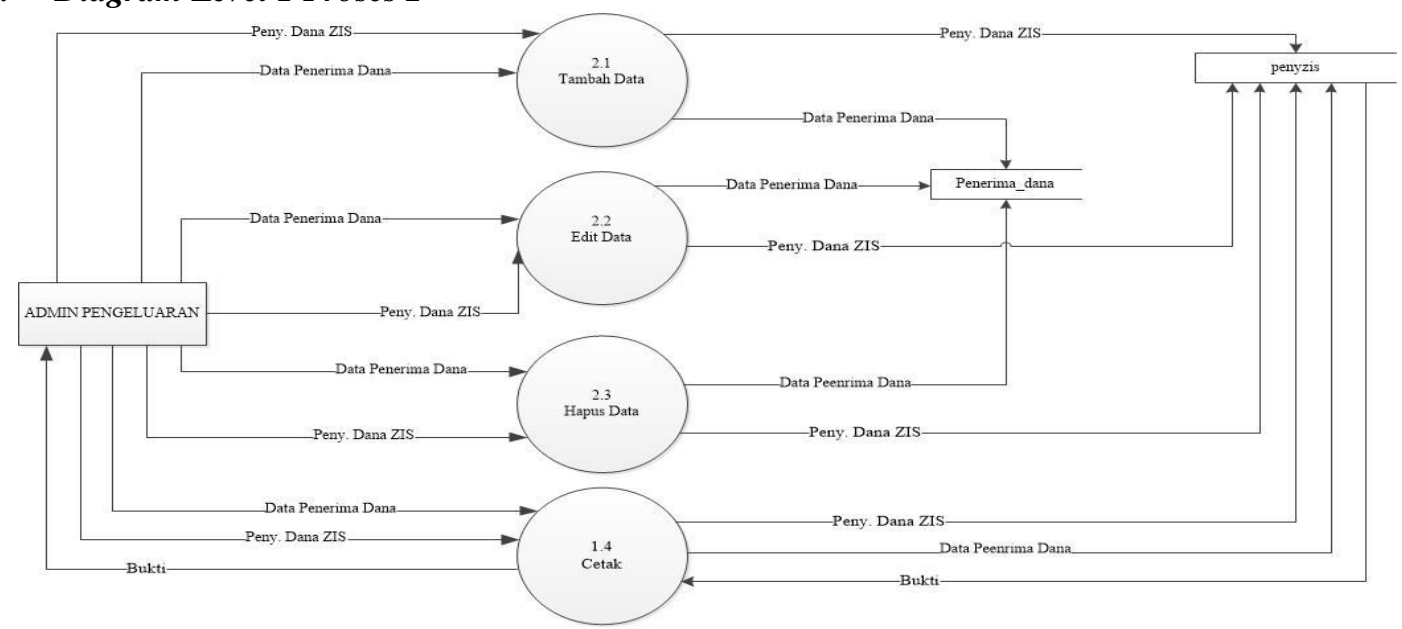

Gambar 8. Diagram Level 1 Proses 2

4.9. Entity Relationship Diagram (ERD)

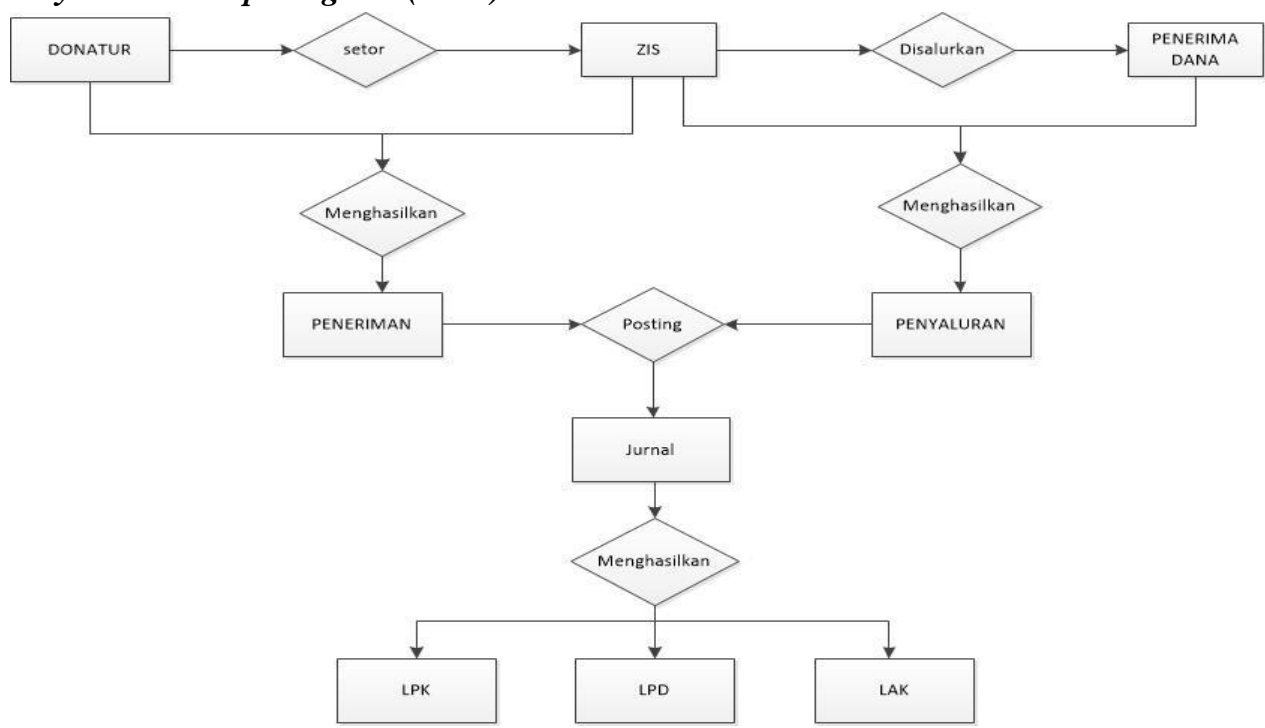

Gambar 9. Entity Relatiomship Diagram (ERD)

\section{Implementasi Antarmuka Program}

Implementasi antarmuka program adalah hasil implementasi dari perancangan sistem yang telah dibuat. Berikut ini adalah Interface antarmuka program.

1. Form Login Bagian Admin Penerimaan

Form login admin yaitu form yang dapat digunakan oleh admin Penerimaan untuk masuk ke Sistem Akuntansi Penerimaan Donasi ZIS. Form Login ini terdapat dua inputan yaitu Username dan Password. 


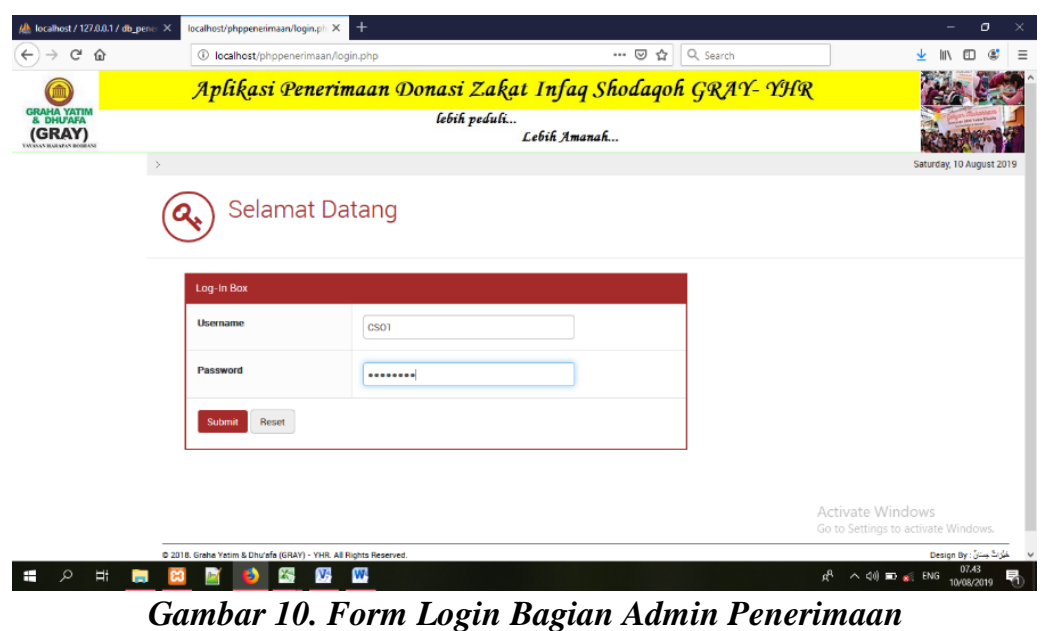

2. Form Menu Utama Bagian Admin Penerimaan

Form menu utama Bagian Admin Penerimaan ini adalah form menu sistem untuk menentukan aksi atau operasi yang akan dilakukan oleh Bagian Admin Penerimaan.

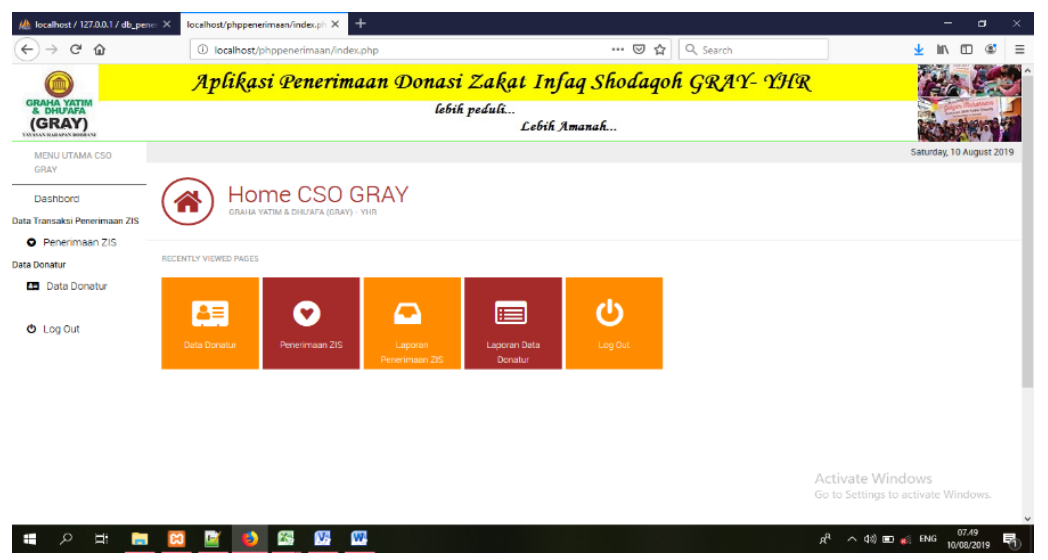

Gambar 11. Form Menu Utama Admin Penerimaan

3. Form Entry Penerimaan Donasi ZIS

Form penerimaan donasi yaitu form yang digunakan untuk menginput data donator dan jumlah donasi yang diberikan. Inputannya terdiri dari No Bukti, Tanggal, Nama Donatur, No_Telp, Alamat, Jumlah



Sistem Informasi Penerimaan Donasi Zakat, Infaq Dan Shodaqoh (Zis) Berstandar Psak 109 Berbasis Web (Studi Kasus: Graha Yatim Dan Dhuafa) - (Khoirotun Hisan, Lena Magdalena, Muhammad Hatta) 
4. Form Hasil Entry Penerimaan ZIS

Form hasil Entry ini menampilkan hasil dari form penerimaan donasi ZIS

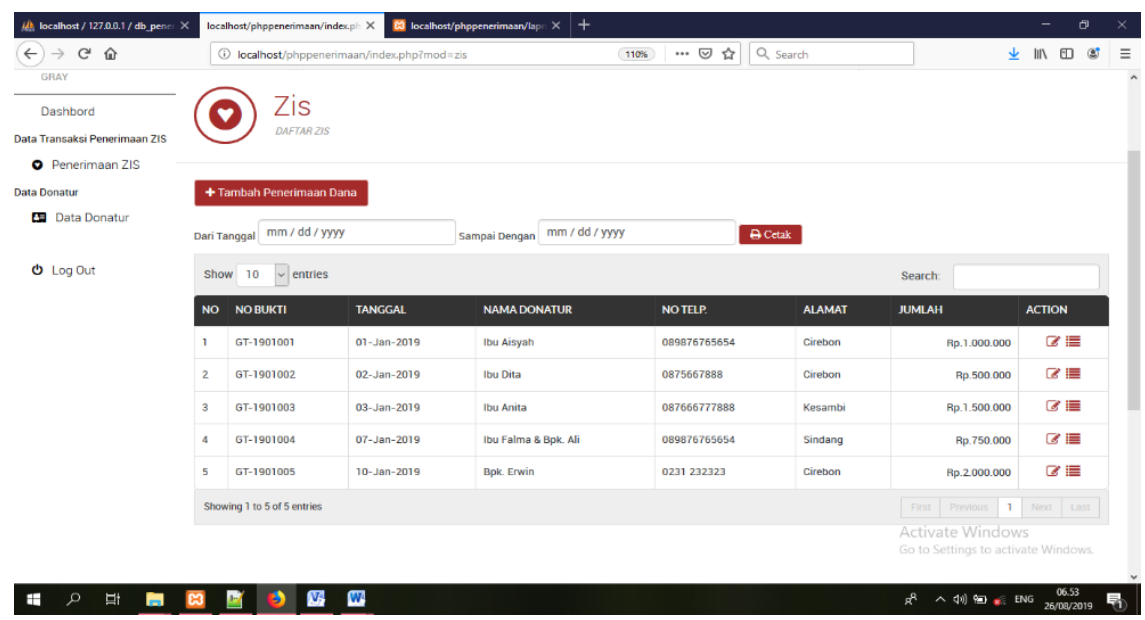

Gambar 13. Form Hasil Entry Penerimaan ZIS

5. Form Entry Penerimaan ZIS Detail

Form ini digunakan untuk menginput penerimaan detail dan untuk mengetahui kategori penerimaan yang diterima dari donatur.

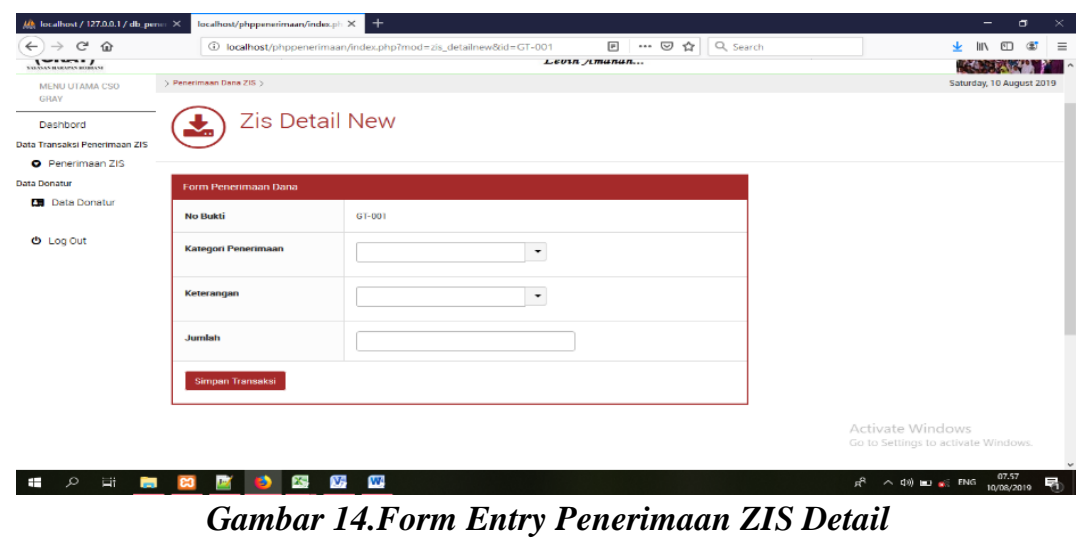


6. Hasil Entry Penerimaan ZIS detail

Tampilan hasil entry penerimaan ZIS detail.

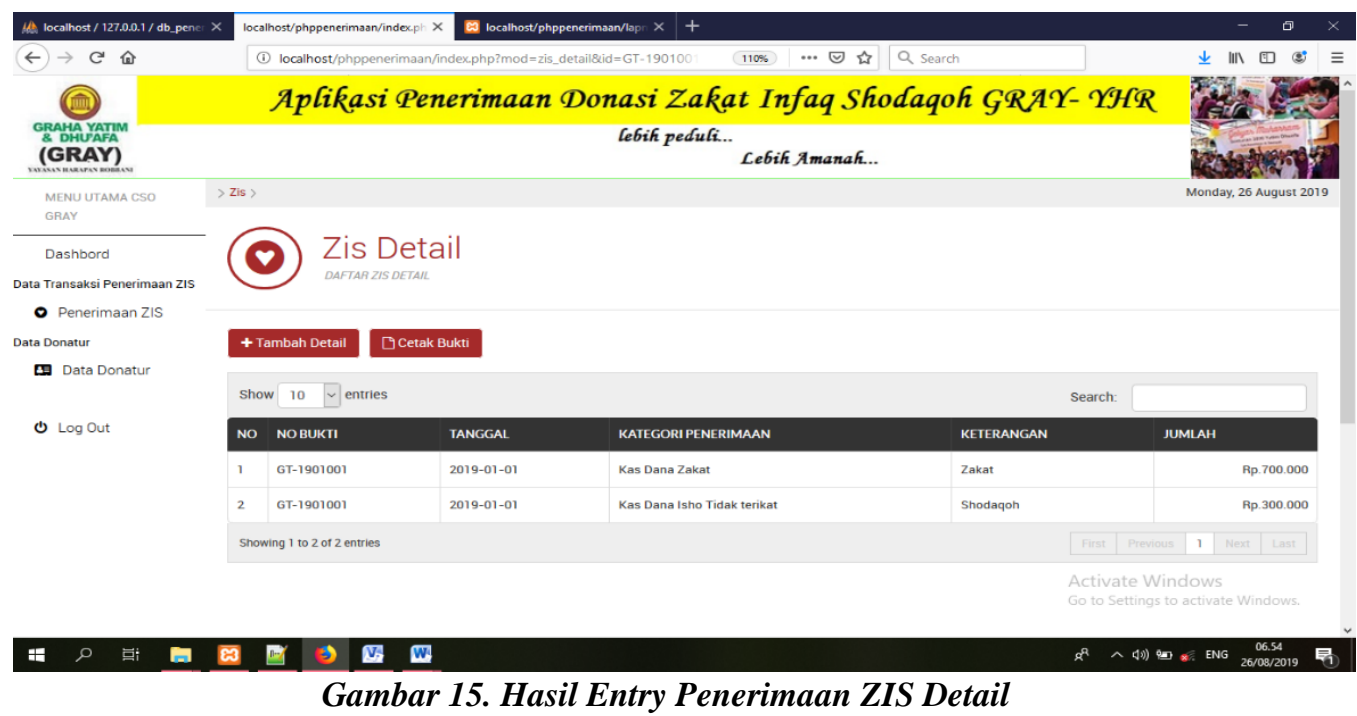

7. Tampilan Kwitansi ZIS

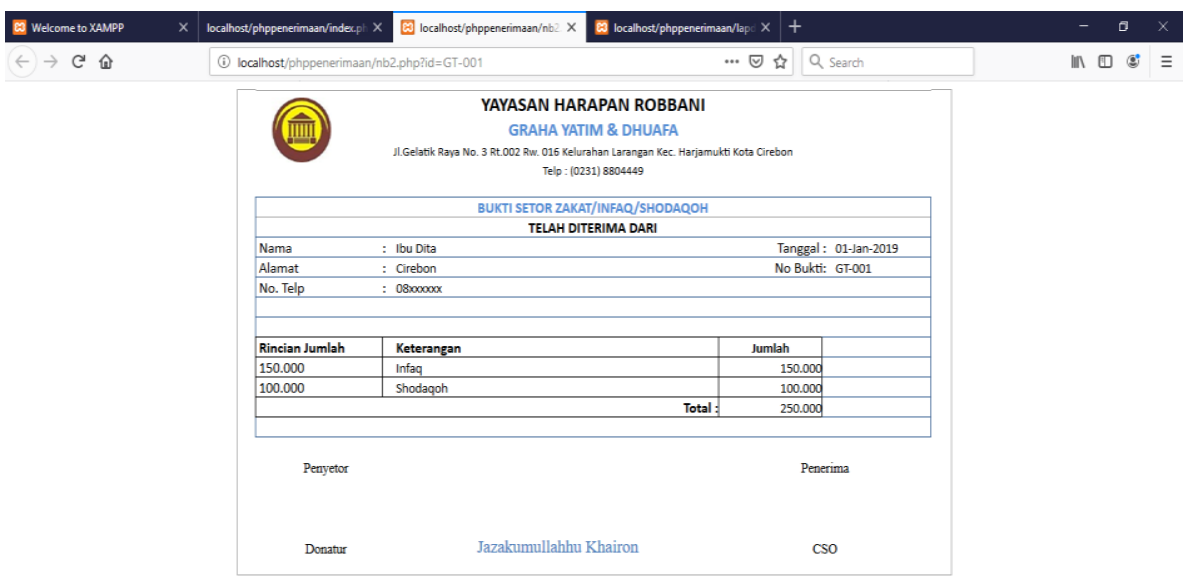

Gambar 16. Tampilan Kwitansi ZIS

Sistem Informasi Penerimaan Donasi Zakat, Infaq Dan Shodaqoh (Zis) Berstandar Psak 109 Berbasis Web

(Studi Kasus: Graha Yatim Dan Dhuafa) - (Khoirotun Hisan, Lena Magdalena, Muhammad Hatta) 
8. Tampilan Laporan Penerimaan ZIS

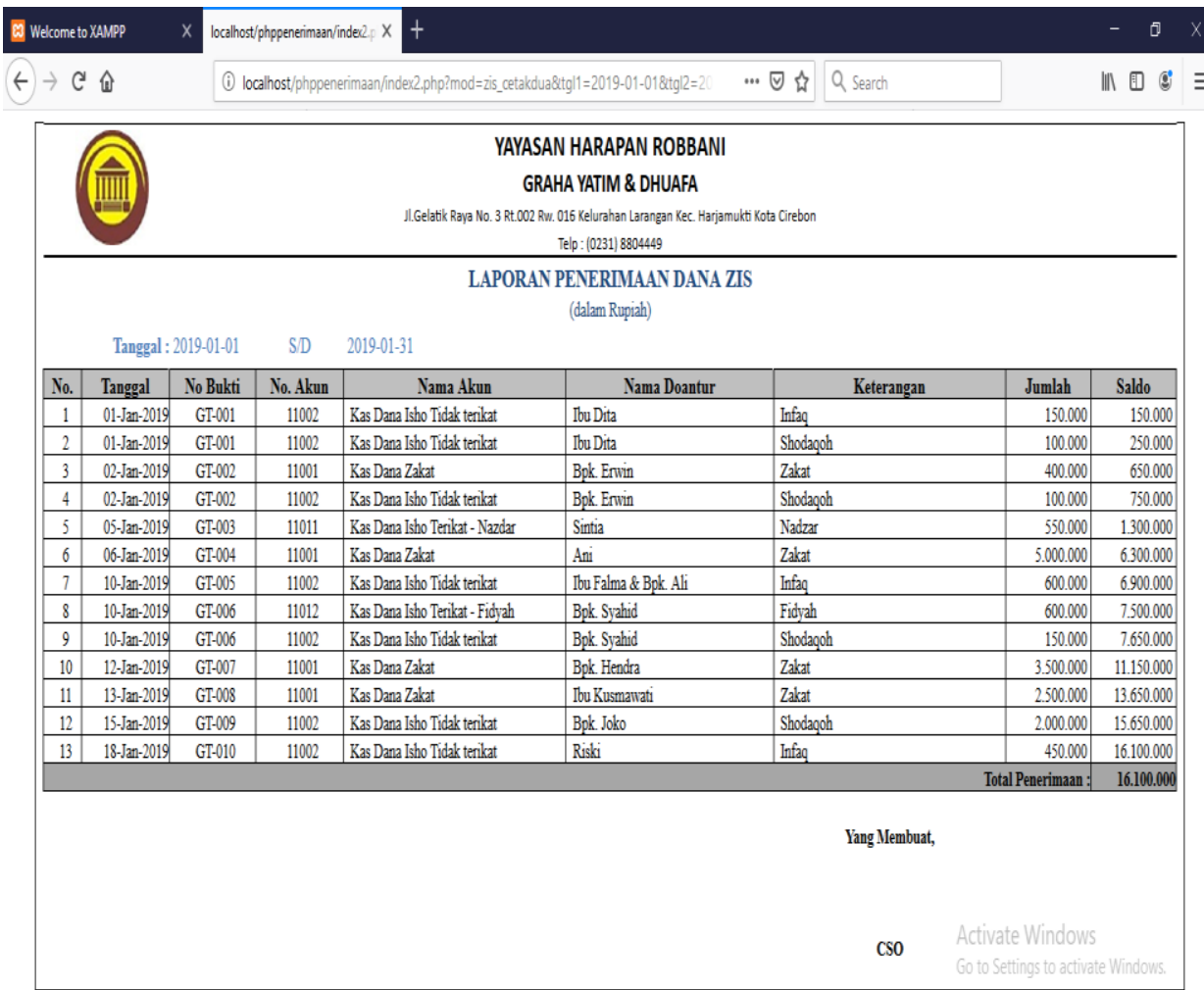

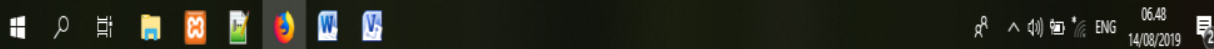

Gambar 17. Tampilan Laporan Penerimaan ZIS

\section{KESIMPULAN DAN SARAN}

\subsection{Kesimpulan}

Setelah penyusun mempelajari dan memahami serta berusaha menyelesaikan permasalahan yang terjadi pada Graha Yatim dan Dhuafa mengenai penerimaan donasi Zakat, Infaq dan Shodaqoh, maka dari penyusunan skripsi ini dapat ditarik kesimpulan sebagai berikut :

1. Sistem Akuntansi ini dibuat untuk penerimaan donasi ZIS di Graha Yatim dan Dhuafa.

2. Prosedur yang terdapat di sistem ini adalah prosedur penerimaan donasi ZIS, prosedur penyaluran donasi ZIS dan prosedur pembuatan laporan.

3. Dengan dibuatnya Sistem Akuntansi Penerimaan Donasi ZIS ini dapat memudahkan proses pencatatan penerimaan donasi ZISx.

4. Sistem Akuntansi Penerimaan Donasi ZIS ini menghasilkan laporan-laporan yaitu Laporan Penerimaan Dana ZIS, Laporan Penyaluran Dana ZIS, Laporan data Donatur, Laporan Penerima Dana, Laporan Posisi Keuangan (LPK), Laporan Arus Kas (LAK) dan Laporan Perubahan Dana (LPD).

\subsection{Saran}

Saran yang dapat penyusun berikan untuk pengembangan selanjutnya tentang Sistem Akuntansi Penerimaan Donasi ZIS Berstandar PSAK 109 ini adalah:

1. Sistem ini belum menyediakan perhitungan zakat.

2. Sistem ini tidak membahas tentang dana amil dan dana non halal. 


\section{DAFTAR PUSTAKA}

[1] Jogiyanto, H.M. 2005. Analisa dan Desain Sistem Informasi: Pendekatan Terstruktur Teori dan Praktek Aplikasi Bisnis. ANDI: Yogyakarta.

[2] Mcleod, Raymond, Sistem Informasi Manajemen, Jakarta : PT. Prenhallindo, 2001.

[2] Purwanto, April, Risalah Zakat, Bandung : Rumah Zakat Indonesia, 2003.

[3] Tata Sutabri, Sistem Informasi Manajemen, Yogyakarta : Andi, 2005.

[4] Ikatan Akuntan Indonesia, 2008. Exposure Draft Pernyataan Standar Akuntansi Keuangan : Akuntansi Zakat dan Infak/Sedekah. Jakarta : Dewan Standar Akuntansi Keuangan Ikatan Akuntan Indonesia

[5] Mahmudi, Sistem Akuntansi Organisasi Pengelola Zakat, Yogyakarta : P3EI, 2009.

[6] Pribadi, A. K. (2010). Sistem Informasi Penerimaan Dan Penyaluran Zakat Dengan Ditribusi Konsumtif Dan Produktif: Studi Kasus Baitul Maal Wat Taamwil Masjid Al-Azhar Cabang Ciledug. http://Repository.Uinjkt.Ac.Id/Dspace/Handle/123456789/21446

[7] Salman, I. M. (2011). Sistem Informasi Manajemen Dana Pengelolaan Donatur Berbasis Web Pada Yayasan Griya Yatim Dan Dhu'afa. http://103.229.202.68/Dspace/Bitstream/123456789/1308/1/Iqbal\%20muhammad\%20salman-

Fst.Pdf

[8] Dwipratama, A. P. (2011). Sistem Informasi Manjemen Zakat, Infak, Dan Sedekah Pada Badan Amil Zakat Nasional. http://Repository.Uinjkt.Ac.Id/Dspace/Bitstream/123456789/210/1/101215Agung\%20pandu\%20d wipratama-Fst.Pdf

[9] Nugroho, Bunafit, Sistem Panduan Proyek Penjualan Retail, Jakarta : PT. Alif Media, 2012.

[10] Nugraha, H. S. (2013). Sistem Informasi Akuntansi Perhitungan Zakat Infak Dan Sedekah Bazda Subang. Jurnal Teknologi Dan Komunikasi Stmik Subang, 4(1). http://Jurnalstmiksubang.Ac.Id/Index.Php/Jtik/Article/View/27

[11] Uqaily, Ali Mahmud, Praktiss \& Mudah Menghitung Zakat, Solo: PT. Aqwam Jembatan Ilmu, 2013.

[12] Alghofari, A. K., Anis, M., \& Wardana, A. W. (2013). Sistem Informasi Manajemen Panti Asuhan $\begin{array}{llll}\text { Yatim } & \mathrm{Pku} & \text { Muhammadiyah } & \text { Cabang }\end{array}$ https://Publikasiilmiah.Ums.Ac.Id/Xmlui/Bitstream/Handle/11617/4132/Ti.001_\%20ahmad\%20kh olid_Ums.Pdf?Sequence=1

[13] Sugiyatno, S., Muhtarom, M., \& Hidayat, M. (2015). Perancangan Aplikasi Muzakki Pada Sistem Informasi Zakat, Infaq Dan Shodaqoh Berbasis Android. Semnasteknomedia Online, 3(1), 4-4. https://ojs.amikom.ac.id/index.php/semnasteknomedia/article/download/857/820

[14] Tamara, N. E., Widodo, A. P., \& Sutanto, T. (2015). Rancang Bangun Aplikasi Pembuatan Laporan Keuangan Lembaga Pengelola Dana Zakat Infak Sedekah Berdasarkan Psak 109 Pada Ydsf Surabaya. Jurnal Jsika, 4(1). http://Jurnal.Stikom.Edu/Index.Php/Jsika/Article/View/617

[15] Hakim, L. (2015). Sistem Informasi Pengelolaan Dana Zakat Untuk Polis Asuransi Kesehatan Fakir Miskin Di Baznas Provinsi Jawa Barat. Prosiding Keuangan \& Perbankan Syariah, 337-344. http://Karyailmiah.Unisba.Ac.Id/Index.Php/Perbankan_Syariah/Article/View/1158

[16] Sujarweni, V. Wiratna, Sistem Akuntansi, Yogyakarta : Pustaka Baru Press, 2015.

[17] Mam, H. F. (2015). Sistem Informasi Perhitungan Zakat Berbasis Android. Skripsi, Fakultas Ilmu Komputer. http://Eprints.Dinus.Ac.Id/16813/1/Jurnal_15864.Pdf

[18] Yudi, Efendi. (2016).Perbandingan PSAK 45 Dan PSAK 109 Pada Laporan Keuangan Masjid AlJauhar.

[19] Mulyadi, Sistem Akuntansi, Jakarta : Salemba Empat, 2016.

[20] Susanto, A. A., \& Aristoteles, A. (2016). Rancang Bangun Pengolahan Zakat, Infak, Dan Sedekah. Jurnal Komputasi, 4(2). http://Jurnal.Fmipa.Unila.Ac.Id/Index.Php/Komputasi/Article/View/1245

[21] Setiawan, Didik, Buku Sakti Pemrograman Web, Yogyakarta : Start Up, 2017

[22] TMBooks, Sistem Informasi Akuntansi, Yogyakarta : Andi, 2017.

[23] Fatansyah, Basis Data, Edisi Revisi ke-3, Bandung : CV. Informatika, 2018.

[24] Rumah Zakat, 2018. Laporan Keuangan Yayasan Rumah Zakat. 